\title{
HEMATOLOGICAL CHARACTERIZATION OF BETA-THALASSEMIA IN SUDANESE PATIENTS
}

\author{
RABAB HASSAN ELSHAIKH ${ }^{1 *}$, SANAA ELFATIH HUSSEIN ${ }^{2}$
}

${ }^{1}$ Department of Hematology and Immunohematology, Faculty of Medical Laboratory Sciences, University of Technology and Science, Sudan. ${ }^{2}$ Department of Faculty of Medical Laboratory Science, University of Gezira, Sudan. Email: rababhassan1892@gmail.com.

Received: 13 March 2020 Revised and Accepted: 20 April 2020

\section{ABSTRACT}

Thalassemia is common inherited disorder among humans, and they represent a major public health problem in many areas of the world. The study aimed to the measurement of hematological characterization of beta-thalassemia in Sudanese patients. Blood samples from 61 beta-thalassemic patients were collected after written consent form obtained from all participants. The frequency of adults (>18 years) was 45 (73.8\%) and children's (<18 years) was 16 (26.2\%); the frequency of male was 27 (44.3\%) and 34 were female (55.7\%). Hemoglobin estimation and red cell indices were carried out using the automatic blood cell counter Sysmex $\mathrm{K} \times 21 \mathrm{~N}$. The results showed that Hb and RBCs indices were varied between mild to moderate and severe decreasing, hemoglobin concentration $(\mathrm{Hb})$ with the mean value of $9.6 \mathrm{~g} / \mathrm{dL}$, with minimum value of $6.1 \mathrm{~g} / \mathrm{dl}$ and maximum of $11.9 \mathrm{~g} / \mathrm{dl}$, while RBCs were increased in all patients, mean value $5.2 \mathrm{c} / \mathrm{l}$, mean corpuscular volume mean was $58.9 \mathrm{fl}$, hematocrit was 30.4 , mean corpuscular hemoglobin (MCH) $18.8 \mathrm{pg}$, mean corpuscular hemoglobin concentration (MCHC) was $31.7 \mathrm{pg}$, and RDW was $18.8 \%$. The method used for hemoglobin electrophoresis was capillary electrophoresis, Hb pattern shows increased $\mathrm{HbA} 2$ and $\mathrm{HbF}$, the mean of $\mathrm{HbA}$ is $78.3 \%$, $\mathrm{HbF}$ is $2.3 \%$, and $\mathrm{HbA}_{2}$ is $6.5 \%$ with the min. value of $3.6 \%$ and max. of $12.2 \%$. While the mean of serum iron was $82.75 \mu \mathrm{g} / \mathrm{dl}, 7 \mathrm{patients}$ showed low level, 19 high level, and 35 were normal level. Comparison of hematological analysis (HbA2) in thalassemic patients coexisted with iron deficiency and without result was insignificant difference ( $\mathrm{p}=0.645)$, this result disagrees with references that say iron deficiency masking HbA2. Nevertheless, the association between $\mathrm{HbA} 2$ and $\mathrm{HbF}$ revealed a statistically significant difference $(\mathrm{p}<0.013)$ and $\mathrm{HbA} 2$ with $\mathrm{Hb}$ was insignificant $(\mathrm{p}=0.260)$.

Keywords: Thalassemia, RBC indices, Hb electrophoresis, CBC, Iron, Sudan.

(C) 2020 The Authors. Published by Innovare Academic Sciences Pvt Ltd. This is an open access article under the CC BY license (http://creativecommons. org/licenses/by/4. 0/) DOI: http://dx.doi.org/10.22159/ijms.2020.v8i3.36436

\section{INTRODUCTION}

Thalassemia is a Mendelian autosomal recessive heritable blood disorder, it is a group of genetically determined microcytic, hypochromic anemia's resulting from a decrease in synthesis of one or more globin chains in the hemoglobin molecule [4]. The most common types are alpha- and beta-thalassemia according to which globin chain is reduced [15]. Beta-thalassemia is classified into three types depending on the severity of symptoms: Thalassemia major also known as Cooley's anemia $[8,16]$. Thalassemia intermediate and thalassemia minor, thalassemia major is more severe. The signs and symptoms of thalassemia major appear within the first 2 years of life, children develop life-threatening anemia, and they do not gain weight and grow at the expected rate (failure to thrive) and may develop yellowing of the skin and whites of the eyes (jaundice) [18]. Affected individuals may have an enlarged spleen, liver, heart, and their bones which may be misshapen. Some adolescents with thalassemia major experience delayed puberty. Many people with thalassemia major have such severe symptoms that they need frequent blood transfusions to replenish their red blood cell supply overtime, an influx of iron-containing hemoglobin from chronic blood transfusions can lead to a buildup of iron in the body, resulting in liver, heart, and hormone problems. Thalassemia intermedia is milder than thalassemia major (Yaish et al., 2009). The signs and symptoms of thalassemia intermedia appear in early childhood or later in life. Affected individuals have mild-to-moderate anemia and may also have slow growth and bone abnormalities (Raffaella, 2015; GHR, 2002). The disorder may occur in the homozygous or heterozygous state. Heterozygotes may be asymptomatic, but homozygotes typically have a severe, often fatal, disease. It involves increased (HbA2) and decreased production of normal adult hemoglobin ( $\mathrm{Hb} \mathrm{A}$ ), the predominant type of hemoglobin from soon after birth until death [6]. Mostly, the patients are diagnosed on routine blood examination. Beta-thalassemia carrier, it is commonly not diagnosed until adolescence or adult life and may be detected in a routine hematological screening examination. The red cell indices, $\mathrm{Hb}$ electrophoresis, and molecular studies give more reliable diagnosis. In thalassemia trait, MCV and MCH are low while MCHC is marginally reduced or normal. Hemoglobin electrophoresis and molecular study are essential for definite diagnosis of $\beta$-thalassemia cases. Normally Hb A2 is $<3.2 \%$, but in $\beta$ eta-thalassemia trait, it is more than $3.5 \%$ [1].

\section{MATERIALS AND METHODS}

A cross-sectional descriptive study was carried out to detect hematological characterization of beta-thalassemia Sudanese patient in Khartoum State, Sudan, during the period of July 2017-July 2019. From each patient, $2.5 \mathrm{ml}$ of venous blood sample was collected in sterile EDTA container. The blood samples were analyzed for complete blood count (CBC) using the automated hematology analyzer Sysmex $\mathrm{K} \times 21 \mathrm{~N}$ (manufactured by Sysmex corporation Kobe, Japan) within $24 \mathrm{~h}$ of blood collection. On the same day itself, the blood samples were screened for hemoglobinopathies by $\mathrm{Hb}$ electrophoresis method (Sebia, France). The inclusion criteria patients were diagnosed as beta-thalassemia, availability of patient demographic data, and laboratory reports (CBC, hemoglobin electrophoresis, and peripheral blood picture, and iron studies). Patients not diagnosed as beta-thalassemia or coexisted with other hemoglobin variants or with other hematological malignancy excluded from the study. Permission of this study was obtained from the local authorities in the area of the study. The objective of the study explained to all individuals participating in this study. An informed written consent obtained from all participants.

\section{RESULTS}

Out of 61 beta-thalassemic patients, the frequency of adults ( $>18$ years) was $45(73.8 \%)$ and $16(26.2 \%)$ was children (18 years), and the frequency of male to female was 27 of the patients were male $(44.3 \%)$ and 34 were female (55.7\%), as shown in Table 1. Hemoglobin estimation and red cell indices were carried out using the automatic blood cell counter Sysmex $\mathrm{K} \times 21 \mathrm{~N}$. The results obtained were as 
follows: Hemoglobin concentration $(\mathrm{Hb})$ with the mean value of $9.6 \mathrm{~g} / \mathrm{dL}$, with minimum value of $6.1 \mathrm{~g} / \mathrm{dl}$, and maximum of $11.9 \mathrm{~g} / \mathrm{dl}$, while RBCs were increased in all patients with mean value of $5.2 \mathrm{c} / \mathrm{l}$, mean corpuscular volume (MCV) mean was $58.9 \mathrm{fl}$, hematocrit was 30.4, mean corpuscular hemoglobin (MCH) $18.8 \mathrm{pg}$, mean corpuscular hemoglobin concentration (MCHC) was $31.7 \mathrm{pg}$, and RDW was $18.8 \%$, as shown in Table 2 . The method used for hemoglobin electrophoresis was capillary electrophoresis; the $\mathrm{Hb}$ pattern shows increased $\mathrm{HbA} 2$ and $\mathrm{HbF}$, the mean of $\mathrm{HbA}$ is $78.3 \%, \mathrm{HbF}$ is $2.3 \%$, and $\mathrm{HbA} 2$ is $6.5 \%$ with the min. value of $3.6 \%$ and max. of $12.2 \%$, as shown in Table 3 . The mean of serum iron was $82.75 \mu \mathrm{g} / \mathrm{dl}, 7$ patients showed low level, 19 high level, and 35 were normal level, Table 4 and Figs. 1-3.

Table 1: Gender and age distribution in the study group

\begin{tabular}{lll}
\hline & Frequency & Percentage \\
\hline Gender & & \\
$\quad$ Male & 27 & 44.3 \\
Female & 34 & 55.7 \\
Age group (y) & & \\
$\quad<18$ & 16 & 26.2 \\
$>18$ & 45 & 73.8 \\
\hline
\end{tabular}

\section{DISSCUSION}

For 61 beta-thalassemic patients, hemoglobin estimation and red cell indices were carried out using the automatic blood cell counter Sysmex KX21N. The results obtained were; overall mean hemoglobin concentration (Hb) was decreased $9.6 \mathrm{~g} / \mathrm{dl}$. Red blood cell count (RBC) $5.19 \times 10^{12}$ cell/L was found to be raised. Red blood cell indices were found to be low (packed cell volume mean cell volume (MCV) $58.9 \mathrm{fl}$, mean cell hemoglobin (MCH) $18.8 \mathrm{pg}$, mean cell hemoglobin concentration (MCHC) $31.7 \mathrm{~g} / \mathrm{dl}$, red cell distribution width (RDW) 18.8); these results agreed with several studies in the literature, for example ([9], Tahir et al., Idit et al.), specially with Dr. Sana, 2013, literature. Furthermore, this study agreed with the data mentioned in Thalassemia International Federation. $\mathrm{Hb}$ electrophoresis was measured by capillary electrophoresis results shows mean of $\mathrm{HbF}$ is $2.3 \%$ which was high, and $\mathrm{HbA} 2$ is $6.5 \%$ with the min value of $3.6 \%$ and max of $12.2 \%$ also shows significant increase which agreed with several studies e.g., ([5]; Mohammed et al., 2014). The mean of serum iron was $82.75 \mu \mathrm{g} / \mathrm{dl}, 7$ patients showed low level, 35 were normal level, and 19 high levels those are mainly due to blood transfusion; unfortunately, data of blood transfusion were missing in this study. Many studies show similar result unless in recurrent transfused thalassemic patient

Table 2: Mean and standard deviation of $\mathrm{Hb}$ and RBC indices in the study group

\begin{tabular}{lllllll}
\hline Parameters & Hb/g/d & HCT & RBCs & MCV & MCH/pg & MCHC/pg \\
\hline Mean & 9.618 & 30.364 & 5.197 & 58.882 & 18.761 & 31.657 \\
Std. deviation & 1.3214 & 3.6247 & .7394 & 6.5545 & 2.9306 & 18.825 \\
Minimum & 6.1 & 18.8 & 3.2 & 44.2 & 13.3 & 2.9644 \\
Maximum & 11.9 & 36.2 & 6.7 & 76.4 & 27.2 & 315 \\
\hline
\end{tabular}

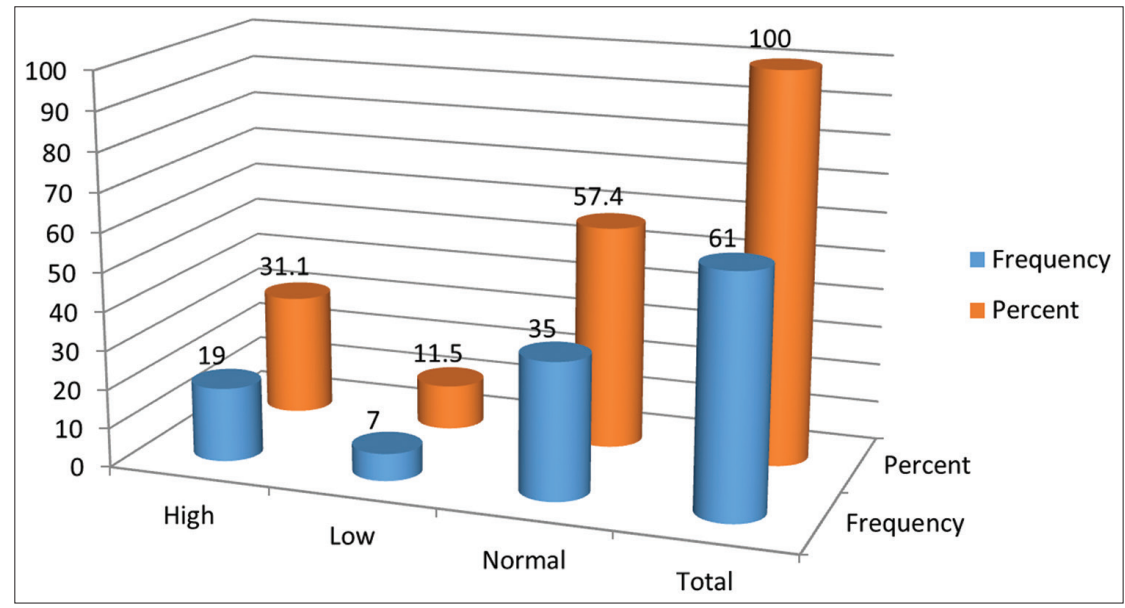

Fig. 1: Frequency of iron level in the study group

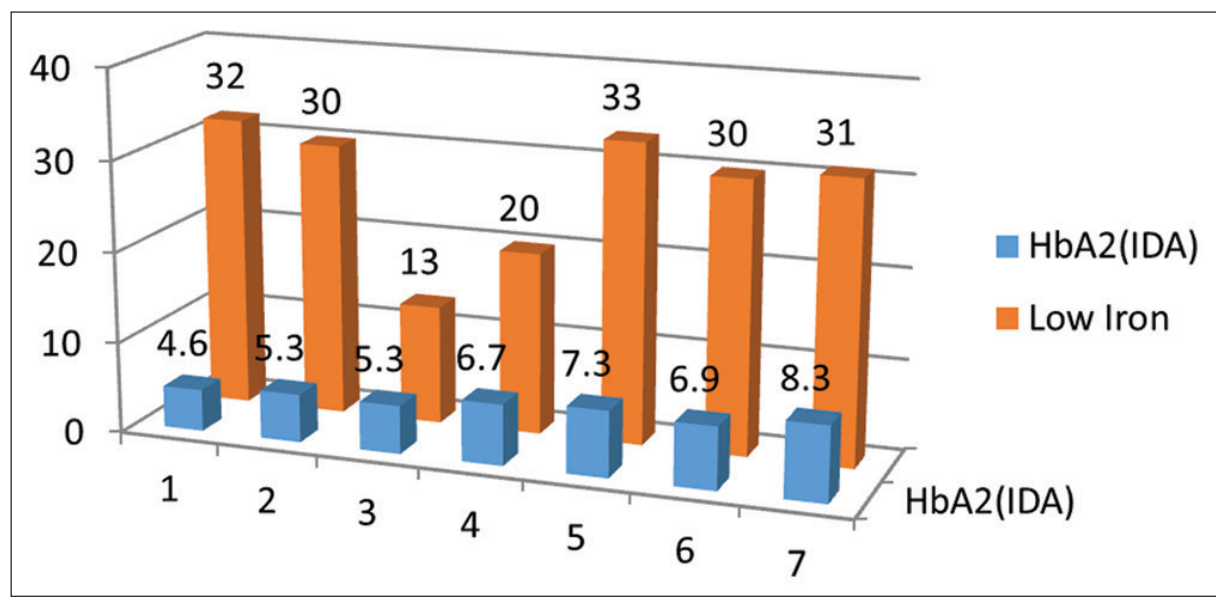

Fig. 2: Hb A2 in thalassemic patients coexisted with iron deficiency 


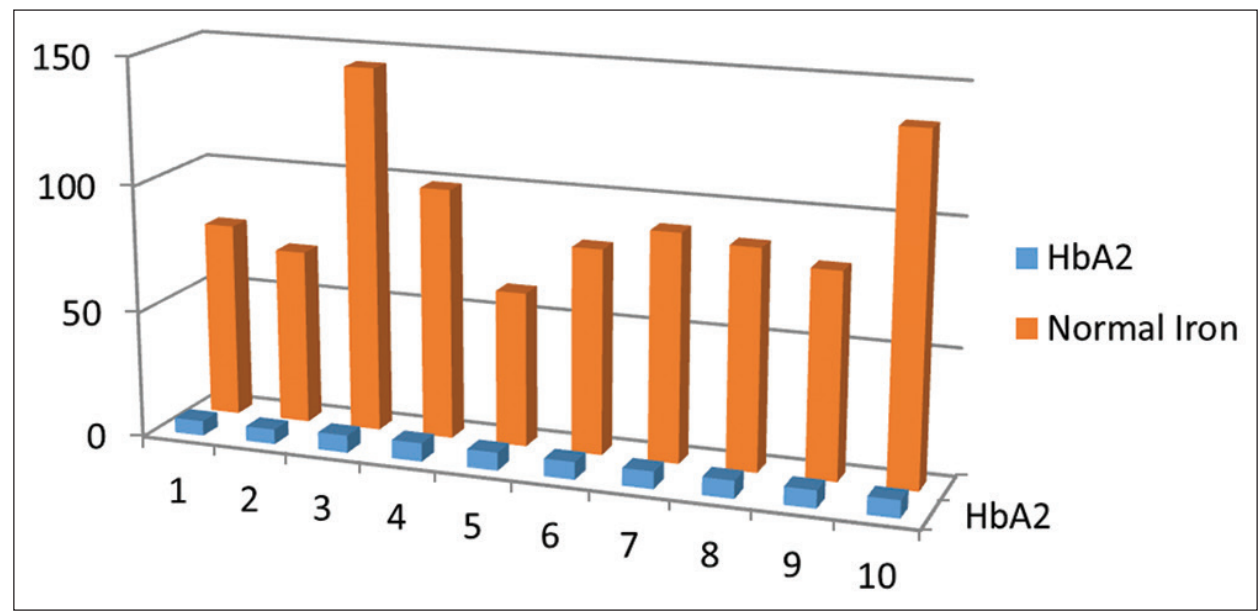

Fig. 3: Hb A2 in normal iron group

Table 3: Hb electrophoresis pattern in thalassemic patients

\begin{tabular}{llll}
\hline Hb electrophoresis parameters & HbA2/\% & HbF $/ \%$ & HbA $/ \%$ \\
\hline Minimum & 3.6 & 0.4 & 70.1 \\
Maximum & 12.2 & 10.4 & 92.7 \\
Mean & 6.498 & 2.277 & 78.289 \\
Std. deviation & 1.3895 & 1.9511 & 3.2221 \\
\hline
\end{tabular}

Table 4: Mean and standard deviation of serum iron in the study population

\begin{tabular}{ll}
\hline & Iron result \\
\hline Mean & 82.75 \\
Std. deviation & 29.112 \\
\hline
\end{tabular}

levels are much higher. Comparison of hematological analysis (HbA2) in thalassemic patients coexisted with iron deficiency and without result was insignificant difference $(p=0.645)$; this result disagrees with many references that say iron deficiency masking $\mathrm{HbA2}$. Nevertheless, the association between $\mathrm{HbA} 2$ and $\mathrm{HbF}$ revealed a statistically significant difference $(\mathrm{p}<0.013)$, that means, there is positive correlation between $\mathrm{HbA} 2$ and $\mathrm{Hb} \mathrm{F}$ and the correlation between $\mathrm{HbA} 2$ with $\mathrm{Hb}$ was insignificant $(\mathrm{p}=0.260)$.

\section{CONCLUSION}

This study was detected the hematological characterization of beta-thalassemia; the results obtained for $\mathrm{Hb}, \mathrm{RBC}$ indices, and $\mathrm{Hb}$ electrophoresis were agreed with several studies. In areas where modern equipment's for diagnosis are not available, the red cell indices and hemoglobin electrophoresis give more reliable diagnosis for betathalassemia and molecular study provides definitive diagnosis. Since there are no symptoms for beta-thalassemia trait, it is very important to discover at early as possible from routine hematological test to prevent beta-thalassemia major offspring's.

\section{ACKNOWLEDGMENTS}

The authors are grateful to staff of pediatric teaching hospital for helping in sample collection. Special thanks to my family for their support, encouragement, and patient.

\section{CONFLICTS OF INTEREST}

Authors declare that no conflicts of interest exist in this paper.

\section{REFERENCES}

1. Firkin F, Chesterman C, Penington D, Rush B. De Gruchy's Clinical Haematology in Medical Practice. $5^{\text {th }}$ ed. London: Blackwell Publishing; 1989.

2. Thalassaemia International Federation. Guidelines to the Clinical Management of Thalassemia. (World Bank 2006, Report of a Joint WHO-March of Dime Meeting 2006). San Francisco: Thalassaemia International Federation; 2000.

3. Eleftheriou A, Angastiniotis M. Hematological Indices Most Commonly Found in Patients with Thalassemia, Hemoglobinopathesis B-Thalassemia Booklet, 1986, Report of a Joint WHO. Nicosia: Thalassemia International Federation; 1996.

4. Hoffbrand AV, Catovsky D, Edward GD. Postgraduate Haematology. $5^{\text {th }}$ ed., Vol. 1. United Kingdom: Blackwell Publishing; 2005. p. 85-103.

5. Sana E. Molecular Genetics of Beta Thalassaemia in Sudan. United Kingdom: Lambert Academic Publishing; 2013.

6. Thein SL. Pathophysiology of beta thalassemia--a guide to molecular therapies. Hematol Am Soc Hematol Educ Program 2005;:31-7.

7. Thein SL. Genetic modifiers of the beta-haemoglobinopathies. $\mathrm{Br}$ Haematol 2008;141:357-66. J

8. Cooley TB. Disorders of the blood. In: Brennemann's Practice of Pediatrics. Hagerstown, MD: W.F. Prior Company Inc.; 1945.

9. Galanello R, Melis MA, Ruggeri R, Addis M, Scalas MT, Maccioni L, et al. Beta 0 thalassemia trait in Sardinia. Hemoglobin 1979;3:33-46.

10. Jameel T, Baig M, Ahmed L, Hussain MB, Alkhamaly M. Differentiation of beta thalassemia trait from iron deficiency anemia by hematological indices. Pak J Med Sci 2017;33:665-9.

11. Roth IL, Lachover B, Koren G, Levin C, Zalman L, Koren A. Detection of $\beta$-thalassemia carriers by red cell parameters obtained from automatic counters using mathematical formulas. Mediterr J Hematol Infect Dis 2018;10:e2018008.

12. Abbas MY. Haematological parameters in Sudanese children with sickle cell disease. Am J Res Commun 2014;2:20-32.

13. Gireel MO, Elkarsani M, Munsour MM, El Taher HB. A screening of hemoglobinopathy in Bija tribes and other minor groups living in Port Sudan. J Med Lab Diagn 2014;5:35-40.

14. Origa R. Beta-thalassemia. In: Gene Reviews. Seattle, WA: University of Washington; 2018.

15. Weatherall DJ. Genetic disorder of hemoglobin. In: Postgraduate Haematology. $5^{\text {th }}$ ed. 1999. p. 91-119.

16. Whipple $\mathrm{CH}$, Bradford WL. Mediterranean disease-thalassemia (erythroblastic anemia of cooley); associated pigment abnormalities stimulating hemochromatosis. J Pediatric 1936;9:279-31.

17. Yaish HM, Arceci RJ. Pediatric Thalassemia. Vol. 9. Sunnyvale, CA: Intermedia.Net, Inc.; 2009. p. 29.

18. Piomelli S, Loew T. Management of thalassemia major. Hematol Oncol Clin North Am 1999;5:557-69.

19. Sebia SR. Department Parc Technologique Leonard de Vinci CP. Lisses, Evry, France: Vinci SA; . 